\title{
Glycogen storage disease due to glucose- 6-phosphatase deficiency type Ib
}

INSERM

\section{Source}

INSERM. (1999). Orphanet: an online rare disease and orphan drug data base. Glycogen storage disease due to glucose-6-phosphatase deficiency type Ib. ORPHA:79259

Glycogenosis due to glucose-6-phosphatase deficiency (G6P) type b, or glycogen storage disease (GSD) type 1b, is a type of glycogenosis due to G6P deficiency (see this term). 